Etnográfica

Revista do Centro em Rede de Investigação em

Antropologia

vol. 17 (1) | 2013

Vol. 17 (1)

\title{
Interurban collective transport and road crashes in Santiago, Cape Verde
}

Transporte coletivo interurbano e acidentes rodoviários em Santiago, Cabo

Verde

\section{Gerard Horta}

\section{(2) OpenEdition}

Journals

Electronic version

URL: https://journals.openedition.org/etnografica/2559

DOI: 10.4000/etnografica.2559

ISSN: 2182-2891

\section{Publisher}

Centro em Rede de Investigação em Antropologia

\section{Printed version}

Date of publication: 1 February 2013

Number of pages: 77-95

ISSN: 0873-6561

\section{Electronic reference}

Gerard Horta, "Interurban collective transport and road crashes in Santiago, Cape Verde", Etnográfica [Online], vol. 17 (1) | 2013, Online since 13 March 2013, connection on 09 February 2022. URL: http:// journals.openedition.org/etnografica/2559; DOI: https://doi.org/10.4000/etnografica.2559

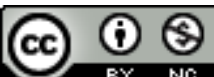

Etnográfica is licensed under a Creative Commons Attribution-NonCommercial 4.0 International License. 


\section{Interurban collective transport and road crashes in Santiago, Cape Verde}

\section{Gerard Horta}

Based on research first begun in Praia (capital of Cape Verde) into the new public organization of its streets and squares - increasingly occupied by cars and other types of motor vehicles -, this article develops a description of the social universe of private group transport on the island of Santiago, and analyses its relationship with road crashes. Its chief focus is the hiace, a generic term designating transportation vans in Cape Verdean society (although they are named after the Hiace model manufactured by Toyota, in this research the word is used as an emic concept). Thus, through the field work completed to date, it outlines the social processes and dimensions in which road crashes involving hiaces take place. Moreover, it puts forward some comprehensive explanations of the causes for the island's high road accident rate within the context of the urban transformation processes underway there. It furthermore reflects on the antagonistic experiences caused by the use of space by both motor vehicle drivers and the pedestrians themselves - space being understood as a social process - in relation to the living conditions and different experiences of the people of Cape Verde.

KEYWORDS: road crashes, urban anthropology, transport, Africa, public space, risk.

Transporte coletivo interurbano e acidentes rodoviários em Santiago, Cabo Verde - A partir da investigação iniciada em Praia (Cabo Verde) acerca da nova organização pública das suas ruas e praças - cada vez mais ocupadas pelos carros e outros veículos motorizados -, o presente trabalho desenvolve uma descrição do universo social do transporte coletivo privado na ilha de Santiago. O protagonista incontornável é a hiace, termo genérico que designa as carrinhas de transporte coletivo de passageiros na sociedade cabo-verdiana (embora tomem o nome de um modelo produzido pela Toyota, nesta pesquisa referimo-nos às hiaces como conceito émico). Assim, percorrendo a pesquisa de campo desenvolvida até agora, propõe-se uma aproximação aos processos e às dimensões sociais em que ocorre a acidentalidade rodoviária protagonizada pelas hiaces. São avançadas também algumas explicações abrangentes das causas de sinistralidade no contexto dos processos de transformação urbana em curso na ilha. Além disso, reflete-se acerca das experiências antagónicas na utilização do espaço por parte de motoristas e peões - sendo o espaço compreendido como um processo social -, na sua relação com as condições de vida e as distintas experiências do povo de Cabo Verde.

PALAVRAS-CHAVE: acidentes rodoviários, antropologia urbana, transporte, África, espaço público, risco.

HORTA, Gerard (gerardhorta@ub.edu) - University of Barcelona, Spain. 


\section{INTRODUCTION}

This article is based on research I first began in 2009 and continued in 2010 and 2011 on the island of Santiago, as part of a project on urban transformations in three African cities (Praia in Cape Verde, Nouakchott in Mauritania and Addis Ababa in Ethiopia). ${ }^{1}$ The study examines the social universe of land transport aboard the Hiace vans, manufactured by Toyota. This vehicle has become the fundamental element of privately owned interurban passenger transport there. On the basis of the field work I undertook, ${ }^{2}$ I examine the social processes and dimensions embodied in this type of transport, with emphasis on the broad spectrum of circumstances in which road crashes involving hiaces occur. In the following pages I will offer a series of comprehensive explanations - provisional at all times - of the causes of this high road accident rate within the context of the urban transformation processes taking place on the island. Consequently, the specific aim of this article is to present a series of arguments as to why hiaces tend to go wrong, and especially concerning the relationship between the system of hiace ownership and road crashes.

The research is the outcome of intense participatory observation made from the inside of vehicles travelling around Santiago. The field work has also included numerous interviews and dialogues with individuals related in some significant way to this sphere: passengers and former passengers, self-employed drivers, salaried drivers, drivers' assistants, senior government officials, public administration officials at the state and municipal level - especially traffic officers and those in the area of transport and urban renewal -, mechanics, insurance company employees, former public transport workers, former hiace drivers, social science academics, students and so on. Naturally, all this has involved time and situations shared in every type of context.

\section{GLOBAL TRANSFORMATIONS OF URBAN SPACES}

With the current process of capitalist globalisation, the world has become an interwoven succession of urban scenarios in accelerated transformation, the instrumental and symbolic functions of which are embodied in heterogeneous practices and representations - frequently antagonistic. On the one hand,

I "Estudio comparado sobre apropiaciones sociales y competiciones de uso en centros urbanos de tres ciudades africanas" (Comparative study of social appropriations and competing uses in urban centres of three African cities), financed by the Spanish Ministry of Science and Innovation (Reference CSO2009-12470), under the supervision of Manuel Delgado and Alberto López (University of Barcelona) within the framework of research by the Grup de Recerca sobre l'Exclusió i el Control Socials (Research Group for Social Exclusion and Control - GRECS), finished in December 2012. This article has been translated from Catalan by Susan Rutherford.

2 Beginning in 2010, together with Daniel Malet, also a member of the Department of Social Anthropology at the University of Barcelona. 
there is the general institutional planning of space use in streets and squares - by governing politicians, economists, urban planners and designers, architects and so on - associated with the resulting public discourses and prevailing media representations on the supposed virtues of these planning projects. On the other, there are the empirical uses and real needs of pedestrians based on their own experiences and social contexts. In African urban environments one observes a certain historical lack of standardisation by the public administrations in the organisation of space, in both city streets and squares and urban and interurban road traffic, and the growing occupation of these spaces by motor vehicles. ${ }^{3}$

Transport system development is thus a key factor when situating new urban planning projects, with the application of arrangement models emerging from the experiences of Western cities through what is known as "development aid cooperation". This is the case of Praia, Cape Verde's capital, under the impetus of Luxembourg's cooperation, in the terms described by Malet (2011: 10), in the building of two new interurban public transport terminals at opposite ends of the city, aimed at phasing out the station at Sucupira, the island's central market, where hundreds of hiaces arrive and depart for destinations all over Santiago. ${ }^{4}$

The core of discussion in this area is grounded in the interpretation of the notion of "public space", already addressed in Horta (2004: 22) within the context of research into Barcelona's hosting of the Universal Forum of Cultures in 2004 with these words: "The free, public use of reason which, according to Kant, lays the foundations of public space has led to this: a double wall which hinders pedestrian transit". ${ }^{5}$ In fact, in view of the ideal conceptualisation and Habermasian standard of "public space" - which, as we see it, is phantasmagorically severed from all types of practices of domination, hierarchical structuring, consumption and social control -, Tarik Dahou (2005) called for an empirical approach within African contexts that would discuss the implications of the policies defined by the public authorities when giving shape to

3 With regard to the social processes linked to the introduction of road traffic in sub-Saharan Africa throughout the 20th century, see the contributions compiled by Gewald, Luning and Van Walraven (2009).

4 For example, this type of "collaboration" has been taking place over the past 20 years in 40 cities in Africa, Latin America and the Mediterranean through the "advisory" intervention of technicians and high-ranking members of Barcelona City Council, who, without any previous public discussion with the citizens of Barcelona and under the umbrella of an inaccurately assumed "solidarity" which consists of who knows what, has transferred - with no ethnocentric embarrassment whatsoever - the same model imposed on Barcelona, within the sphere of "public space" planning, to Tangiers, Gaza, Maputo, Niamey, San Salvador, Medellín and other cities. For the case of Maputo's Baixa Cidade in 2010, see Ribas (2010).

5 A critique that was later treated in greater depth, based on field work carried out in Barcelona's Rambla del Raval district from 2007 to 2009 (Horta 2010a). 
such spaces. It should be kept in mind that the concept of public space owes its success to the use made of it by politicians and urban governors, architects and urban planners over the past 25 years. Indeed and as Delgado (2011: 15-27) points out, if we read the classic works by Jane Jacobs (201 l [1961]), Raymond Ledrut (1973), Amos Rapoport (1978), Jean-François Augoyard (2010 [1979]), Kevin Lynch (1985), Henri Lefebvre (1976), and William H. Whyte (1988), we notice that the concept of public space appears only very rarely and, when it does, it is simply as an equivalent to "streets" and "squares". In 1984 Isaac Joseph employed the "urban space" concept - characterised by an extreme succession of meetings and exchanges of information within mobility contexts (the kind of situations that Charles Baudelaire and Georg Simmel put forth over a century ago) -, while in 1963 Erving Goffman understood public space to be the space in which relations developed in public, as people physically met by chance in spaces through which they walked, spaces of relating in public and for relating in public. Lyn H. and John Lofland understood public space to be city areas to which everyone in general had access, including public equipments (say, buildings, airports, underground networks, public areas in private buildings, etc.), and compared this notion of public space to that of private space, bound by legal access restrictions (Lofland 1985 [1973]; Lofland and Lofland 1984). ${ }^{6}$ Here, then, the understanding of space is explored as a social process: one that is dynamic and therefore, subjected to all sorts of contradictions, affirmations, struggles and relations involving power. It deals with recognising the existence of experiences - both individual and collective - and of antagonistic models with regard to people's space appropriations, for

6 It is true that from the field of political philosophy the concept of public space has developed into a category that refers to the public sphere as an evaluation of the exercise of power by a group of people, within the context of certain forms of social linkage. Yet despite this, the generalised use of the term public space that has come into use since the late 1980s and early 1990s, understands this concept on the basis of a mixture of interpretations with clear political and economic connotations. This mixture embraces: (1) the entirety of places of free access; (2) the scope in which a certain form of social linkage is developed; (3) the scope of a specific type of power relations. In the ancient Greek agora there were no slaves, woman or children. Likewise, the exploitation of the expression "public space" by urban governors and politicians, city planners and architects seems to be almost systematically associated, not with a morality but rather with the legitimisation of classist policies in order to perpetuate certain practices and representations of the city, geared towards directing the experiences of pedestrians in terms of political obedience and formal commercial consumption. The supposed equality of relations in public space touted by citizen-focused speeches is disproven by the very processes of real estate speculation, gentrification, social control, repression, dominance and exploitation. The idealistic representation of public space as one that is harmonic, neutral, idyllic and free of social unrest becomes a mere fallacy in the society of capitalist classes in Europe and/or Africa). This obstinate rhetoric intended to reveal the supposed boons of public space, not as an analytical category, but rather as an instrument for administrative action, and rationalising control over urban planning interventions has yet to take root in Cape Verde. It is a tool indissolubly associated with the grooming of people within the field of the discourses and representations surrounding the supposed values of "citizenship". 
example, the pedestrian versus the driver. According to Lefebvre (1991), space appears as a framework, a reproduction and an appropriation of the persons experiencing it. Thus space, as a social phenomenon produced and reproduced by the practices of people and societies, invariably becomes a social process - a social process in ongoing development; a dynamic space that, over and above the standardisations of urban designers, planners and organisers, is the object of its building and use by those who travel in it.

\section{VEHICULAR TRAFFIC, INTERURBAN TRANSPORT AND EXPERIENCES OF SPACE}

The field research on the island of Santiago has entailed compiling information on and analysing different fields in a merely contextualising manner: the historical process of road transport and communications; the political, economic and cultural framework in which this takes place; the administrative management of hiace van operation in different spheres - legal, economic-labour and road structure, and also in terms of the regulation of their practice (parking spaces, scheduling, ${ }^{7}$ issuing of licences to drive hiaces, central parameters at the scale of the road culture in driving schools, setting prices for the trips, etc.) -, based on the fact that there is a certain laissez-faire attitude on the part of the public administrations; the primary routes - the Praia-Somada-Tarrafal axis and secondary ones - those that set out from these towns for the surrounding areas and/or along the coast -, and the relationship between hiaces and hiluxes (Hilux is another model manufactured by Toyota; those are pickup trucks that use awnings as roofs, covering the most complicated stretches to small towns and villages, and, because the ride is cheaper, compete with hiaces on some secondary routes); the current state of communication routes in proportion to the trips that hiaces engage in; ${ }^{8}$ the hiace ownership system; the lack of any formal structure in the relationship between vehicle owners and salaried drivers, accounting for close to half of the drivers on the island; the drivers' resulting labour instability - low salaries, no employer's liability insurance in the event of accidents, the highly seasonal nature of the job, and severe financial

$7 \quad$ Hiaces have no set arrival and departure times: as a rule, most passengers find it difficult to predict with any degree of certainty when they will reach their intended destination.

8 At the end of 2009 only one main road, between Praia and Somada, proved to be asphalted. A year later the road from Somada (at the island's epicentre) to Pedra Badejo (on the east coast) was also asphalted, as was that which joins Ribeira da Prata (on the northeast coast) to Volto do Monte (in the centre, slightly to the north of Somada and next to the southern side of Serra Malagueta). At this writing in late 2011 , the inland road from Tarrafal, in the extreme north, to Somada is being asphalted. The other - secondary - roads are paved with cobblestones, following the Portuguese colonial model; their maintenance in certain areas (largely due to falling rocks in mountainous areas affected by erosion and rain) is ongoing. The byways or tertiary roads in the interior are unpaved and here transport is carried out by hiluxes. 
pressure which obliges them to work close to 14 hours a day at least six days a week, usually without a yearly holiday.

Some employers own four or five hiaces, and approximately half of the employers are Cape Verdeans who work in Europe or the United States, ${ }^{9}$ while the other half are from Praia, Somada and Tarrafal. In the case of Tarrafal, the majority of drivers, 60 to $70 \%$, own their vehicles, meaning that their driving tends to be more cautious, at least at the outset, since they have a single vehicle on which their livelihood depends, and they have to be careful with it. In contrast, in Somada and Praia most drivers work for someone else.

Likewise, I have analysed the space management of hiace trips throughout the island; competition among drivers for clientele; organisation of the boarding and de-boarding of passengers (at times a youth helps the driver to seek them out, by either shouting out of the co-pilot's window, or getting right out on the street to literally harass potential passengers: these are recruiters, helpers or angariadores) $;{ }^{10}$ the recurring patterns of socialisation inside the vehicles during the trip; the habitual conflicts and solution (or not) of the problems entailed in structuring the trip; the technical elements of the hiace van - passenger seating arrangement and the respective passenger load in five rows of seats for 12, 15 or 18 people depending on the model (occasionally, the hiace has been known to take even 30 passengers), with no doors on the left side other than that of the driver; the hygiene conditions of the exterior and interior of the vehicle; the job of the professional cleaners; ventilation - hiaces do not have air conditioning systems and, because of the island's climate, are always driven with the windows wide open; symbolic elements, such as the name of the vehicle, ${ }^{11}$ and its interior decor; the inside and outside colours; the background music and genres the driver selects throughout the trip (morna, suki, funaná); payment methods (in general, the passenger gets out of the vehicle and pays the driver through the front right-hand window); styles of driving

9 See Claudio Alves Furtado (1993) concerning the transformation of agricultural structures in Cape Verde for a better understanding of the changes that have occurred in recent decades in the economy, division of labour and the new needs in terms of mobility; and João Lopes Filho (2006) for the links among Portuguese colonisation in Cape Verde, the development of slavery, and the direct relation between its abolition in the 19th century and subsequent emigration from the island.

10 At times selected by the employer for the purpose of controlling the real revenue produced, often they are relatives of the hiace owner.

11 In early 2010 front and rear signs were formally prohibited. Gracing the upper part of the windscreen and rear window respectively, they led to all types of expressive depictions of the vehicle. Thus an analysis was carried out on who performed the ritual of naming the vehicle, how the name nourished the vehicle's identity, and the effects prompted by one name or another as a means of luring clientele. It is not that the driver expressed his own identity this way: one would say instead that the name revealed his loyalties and allegiances and hence his attitudes towards his love life, religion, political affiliations, geography, sports, family background and/or driving style. However, even though a vehicle might be named Tranquilo, it would not necessarily be the result of "calm" driving. 
along the roads in relation to the condition of the latter - there is a conspicuous absence of signage and public lighting - and to the somewhat precarious police control established: owing to a shortage of officers (in the opinion of the different police officers) and the police officers' community ties to the areas where they work, which dissuades them from fining those who might be their own neighbours or family members (according to the passengers) -; the uses of the horn, voice and lights - here the horn is used when hiaces cruise the village streets recruiting new passengers other than at the established pick-up and drop-off points: the name of the last stop on the itinerary is shouted out. For example, while in Tarrafal, the driver, assistant or both bellow, "CalhetaCalheta-Calheta!!!" and punctuate this with two short honks of the horn. ${ }^{12}$

The beginnings of this research were partly reflected in Horta (2010b) and certain dimensions, such as the lack of association processes among hiace drivers in Santiago (in the case of both vehicle employees and owners) have yet to be addressed, even insofar as describing the reasons for their historical absence over the last 25 years. In this case, Carlos M. Lopes' contribution $(2009,2010$, and particularly, 2011) is mandatory reading owing to his extensive field work in Luanda, Angola on the evolution of public transport and the association processes of the candongueiros - the name given to Angolan hiace drivers, whose vehicles are known as azulinhos, on account of their blue and white colours.

In a nutshell, examining a transport system such as that of hiaces on the island of Santiago leads one to view Cape Verdean society on the whole as a complete social fact: that of a society aboard a van in motion through its occupants in their sociological, diachronic, synchronic and psycho-physiological dimensions (Marcel Mauss 1991 [1923-1924]). In other words, the complete social fact appears in three dimensions at once: we find the sociological dimension and its synchronic aspects; the historical dimension and its diachronic aspects, and finally the physio-psychological dimension. As LéviStrauss observed (1991 [1950]: 23-27), this coincidence only takes place in individuals. For the purposes of our study, we can refer, for example, to hiace drivers, immersed in a series of dynamic processes - legal: verbal contracts with the vehicle owners; economic: working conditions; aesthetic: the symbolisation of the vehicle through colours, décor, music; religion: the name and explicit meaning of the vehicle though signage on the hiace's front and back windows with slogans often originating from the Catholic universe. What's more, we recognise different milestones in the history of each person: the driver was formerly a hiace user; he worked at different jobs before becoming a driver; at one point in his life he became a salaried driver; and perhaps the 
day will come when he will drive his own vehicle... However, one clearly has to point out the experience each driver has had in his job and the hiace journey itself: we witness psychological and physiological aspects - driving reflexes, natural inclinations that make them more anxious or more relaxed, organic or mental needs, driving conceptualisation - blend with the collective representation of hiace driving as a powerful expressive and instrumental element of everyday life within the society of the island of Santiago. Hiace transport condenses many social dimensions: from the social prestige of the driver in the eyes of the women from the different villages he covers - "a girl in every village"-, to the labour exploitation of the salaried driver, who is often victimised. How can the risk perceptions of many drivers be verified if not by noting their different risk experiences depending on whether they are salaried drivers or driver-owners? Using the expression "hiace system" with Daniel Malet has nothing to do with the functionalist perspectives that conceive society as fully coherent, self-enclosed machinery, but rather with the need to recognize, understand and analyse the dynamic social phenomena involved in hiace transport in relation to the social phenomenon that envelops them. In this respect social is real to the extent that it takes place within a society in which we can only investigate one moment of its development. Hiace transport as a complete social fact does not cover merely economic or legal aspects, but also overlaps aspects having to do with politics, religions, labour, gender relations, the past, the present and different notions of the future, ordinary and extraordinary events, webs of meanings that at times are perforated, consents and impositions, power relations and forms of solidarity, etc. A serious approach to road crashes required a minimum contextualisation of this field of study in relation to its contexts.

Let's now focus on the aspects related to road accidents caused by the recognised link between the different social fields that account for them and certain uses of space. The plethora of reasons approached in order to understand this increasing rate of motor vehicle accidents on the roads, right in the historic centre of the capital Praia and in the small towns, reflect not only a concatenation of antagonistic experiences in the streets, but also a broad spectrum of conflictive social dimensions. On the one hand, we find public standardisation and the drivers' imposition of private usage of streets, squares and roads; on the other, everyday uses and appropriations by the pedestrians: for example, what is socially understood and traditionally enjoyed as a play area by and for children is conceived and employed as a fast track by and for certain drivers. Other dimensions are the relationships between road crashes and the hiace ownership system; the non-existence of labour unions and civic associations advocating the defence of both employee and passenger interests; the lack of a public passenger transport organisation in the fields in question as a whole; the fierce competition among drivers; the labour conditions they 
have to cope with - at times causing or intensifying anomic processes of alcohol abuse; the most varied technical issues (types of road pavement; signage; the role of the police in streets and roads; the use of speed bumps; the shift in the centre of gravity of overcrowded vehicles...); the social risk perception with respect to "good" and "bad" driving; and also the symbolic construction and the spectacularisation of hiaces.

All this is examined in light of the analysis of paradoxical experiences in the use of space - space understood as a social process - in relation to the living needs and conditions of Cape Verdeans. On an interurban scale, the competition or encounter between traffic and pedestrians is part of the everyday landscape. The volcanic orography characterising the island of Santiago, the density and distribution of vegetation during rainy periods - reaching out to the very roads - and the precarious condition of communication routes once built, not only in terms of the lack of sidewalks for pedestrians - non-existent on interurban roads - but also of the uneven sides of roads, in other words, the absence of spaces along which the pedestrians can travel on foot - even at their own risk-, make it possible to understand why they find themselves having to compete with vehicles when in transit.

It is true that there is very little vehicular traffic, owing to the limited financial means of the vast majority of the population - other than "homebound traffic" to Praia on Sunday afternoons when seemingly all vehicles take to the roads. Despite this, the high frequency of passing hiace vans, particularly at certain times of the day, adds an equally high degree of risk for pedestrians: this occurs on the interurban thoroughfares themselves and in the small population hubs that they cross.

The interurban roads interwoven by hiaces connect countless settlements on the whole in close proximity to each other, and it is quite common to see pedestrians ambling along the roads. On many occasions these are students, from four to 18 years of age who, alone or in groups but unaccompanied by adults, go back and forth to school; on others, they are adults, even with livestock - characteristic in villages like Tchon-Bon in the north, close to Tarrafal. In the 1970s and earlier, these were dirt roads, not even made of cobblestones, and their use by pedestrians should never have been extended to include vehicular traffic. The culture and road experience, then, fail to inculcate the type of respect, alarm, or attention shown by pedestrians in other comparable contexts in the industrialised societies in the north of the island. In other words, even though hiace vans have been familiar to residents and pedestrians for 20 years, culturally speaking they are still regarded as newcomers.

It should also be said that these very interurban thoroughfares that cross the settlements are scenarios for a variety of uses by both adults and minors: in the case of boys and girls, they are perceived as places for casual or more formally arranged get-togethers and recreation, often as yet another extension 
of the outdoor domestic space - along with the courtyards and sandy areas in front of some homes -, meaning that, socially speaking, the invading hiaces are perceived as more intrusive or alien to the road than the boys and girls who play there. In other words, the Cape Verdean social logic of passing time, chatting, watching and romping in the streets surrounding the homes has little to do with the numerous uses that vehicles make of the space. And yet it is the people who have had to adjust to the uses made by drivers of the roads and the streets.

While private vehicles using these roads are relatively few, a high percentage of these are hiace vans. And, unquestionably, those that step hard on the accelerator fail to take into consideration the potential risk situations that their transit causes.

Granted, the drivers know full well how to handle these situations. On the whole they are technically very good (despite having received a formal road safety training that tends not to stress the most conflictive aspects of driving). However the oppressive routine caused by stiff labour competition and the everyday toll inflicted by the job often leads them to travel at high speed. It is not the slightest bit unusual, for example, for hiace drivers to run over chickens and small animals right in the settlements, or dogs on the interurban roads. The recurrence of head-on or lateral collisions, people being run over, and crashes involving hiaces alone thus demands that we take a closer look at the social factors that influence how driving is conducted and its consequences. See Horta (2010b) - together with the associated bibliography - for the assessment of the principles through which road accidents are understood, the data universe on Santiago's total number of vehicles and its accident rate and, especially, the accounts of the life and work experience of drivers, passengers and public servants in relation to the interurban transport system on this island of 250,000 inhabitants. ${ }^{13}$

What follows is a bare synthesis of the factors that, at this point, are considered most relevant for understanding road crashes prompted by hiace vehicles. It is a mere summary devoid of the direct transcriptions of the experiences narrated by the actors themselves.

13 For comparative trans-cultural approaches in the field of road crashes, see L. Montoro (2005). Also Buxó (2007: 346-351) and Buxó and Torrijos (1999), where the authors explore the history of prevention in the West in relation to risk concepts and safety, and present a proposal for road education aimed at children and young people which would include, according to the synthesis of Buxó herself: (1) a definition of the road event and the creation of scenarios of possible situations based on a selection of risks and threatening conditions at intersections and signals; (2) an identification of the issues arising from specific problems together with the development of an analysis of what might occur and other collateral effects; and, finally, (3) a programme teaching techniques and skills that would make it possible to assemble risk repertoires - how far one can go and how to find alternatives in risk situations. 


\section{CAUSES OF ROAD CRASHES INVOLVING HIACES}

One of the chief reasons for road crashes is the fierce competition among drivers, particularly non-owner drivers in the area from Somada to Praia, due to the highly seasonal nature of work, with the subsequent lack of stability and instilling of states of uncertainty and anxiety, added to the precarious salary and overall working conditions. For example, the employer generally does not provide paid sick leave for the driver (this is each employer's personal decision), and the workdays are very intense, as has already been pointed out. This creates the need to make as many trips as possible, thus accounting for the high speed of many hiaces and the risk entailed in using road infrastructures that at times are inadequate. ${ }^{14}$ And too, main roads with asphalt or those in the process of being asphalted strike them as an incentive for higher speed - as occurs between Praia and Somada. In the Calheta area (in northeastern Santiago) and Tarrafal (in the north) far fewer accidents take place. The majority accumulate on the outskirts of Praia, where there is significant vehicle transit. Such traffic build-up reveals extremely tight competition for clientele and the need to reach the destination quickly in the hopes of undertaking yet another trip as soon as possible in order to satisfy the urge to earn. Be that as it may, the types of vehicle ownership and their link with labour conditions clearly influence the way that driving is performed.

A second reason would be the pavement conditions: many roads are made of cobblestones, following Portugal's historical colonial model, and in certain areas these are loose despite the daily presence of male and female workers walking along their edges, especially in the mountainous areas, where fallen rocks, caused by irregular rainfall, have to be removed.

A third aspect, linked to the second, is the lack of signage on old roads. This is seen not only in the surface marking, i. e. continuous or discontinuous lines, but also in the shortage of traffic regulation signals, including traffic lights in populated areas and above all at city entrances and exits. Parallel to this, road lighting is virtually non-existent.

A fourth reason would be the dearth of police control along the roads and areas most worthy of the term high risk. The police do not supervise in any daily or rigorously disciplined manner, either on the roads or in the towns, except during major operations prompted by the celebration of festivals drawing people from different towns. A police officer tends to work in the same

14 Hiace ownership means an investment for an employer who has two, three or four drivers working for him. As has been said, a considerable part of those vans belong to Cape Verdeans emigrated to Europe or the United States whose only interest lies in ensuring themselves a fixed income at the end of the month. There is certainly the overall perception on the part of the employers that their salaried drivers systematically cheat them out of part of the takings; the drivers, in turn, question the impossibility of working in a reasonable way, given their poor salary and working conditions. 
place where he lives, where he has his friends and family. And in small towns and villages, almost everyone ends up being someone's friend or family member, meaning that traffic rules are not enforced firmly enough. According to both high-ranking police officers, and ordinary traffic agents, they do not have the sufficient technical and human means. Despite the truth of this, certain drivers and passengers cause another practice to be added, one that is invisible to the public eye in so many societies: a permissiveness, up to a point generalised, that the police on the whole maintain with respect to traffic involving vehicles whose owners are themselves police officers or state officials. This has to do not only with keeping one's licence up-to-date but also the passenger overload itself. Furthermore, certain overload situations experienced by many passengers are examples of solidarity among drivers, as is the case of the last hiace to leave at night, i.e., the last possible vehicle available for reaching one's destination. The absence of interurban public transport makes dependence on hiaces absolute. In the end the police have to perform the supervisory role that should be played by the citizens themselves.

A fifth reason, central to road crashes, has to do with the previously mentioned fact that hiaces cut through countless villages whose residents, above all boys and girls, and animals - goats, dogs, chickens, pigs, even cows -, spend time and travel along that same road that hiaces cross, often at top speed. The residents occupy each village's central streets, now transformed into thoroughfares, as if they were extensions of their homes. Here one must stress the extent to which risk perception differs from one social and urban-planning context to another. As Manuel João Ramos (2011) points out in reference to Addis Ababa, the social evaluation of pedestrians' rights is very low: the cognitive distance between drivers and pedestrians, in terms of spatial experience, interpretation and adaptation, is vast; and the negotiation or struggle for space, intense - see Fiori (2010) for Bamako; Choplin (2009), and Alonso Cabré and Nucci (2011) for Nouakchott.

It was Mary Douglas (1985) who first suggested the inseparable link between risk perception and the social building of value judgements as a means for controlling social norms and thus as a category through which the ever-changing evaluations of a society are established with respect to its certainties and uncertainties. No human being is free of "cultural prejudices" and, in this regard, social representations of risk are dynamically revealed through people's social experiences - social situations, processes and structuralisations. Indeed, one thinks of such concepts as risk society (Beck 1992) - for example, on account of the technological changes in transport methods - and the surmounting of this very risk by its space, time and social limits (Beck 1995) - exemplified in a situation as simple as the sale, in Europe, of a second-hand hiace in poor condition that will see its precarious driving life prolonged on Santiago roads. 
Within this context, we see the interesting paradox put forth by Moreira (2011) in her analysis of the relationship between risk perception and accident accumulation zones (AAZ) in Portugal. Smeed (1974) relates the increase in risky behaviour by motor vehicles to improved infrastructures and technology. Bellaby (1990), on the other hand, is of the opinion that discipline in vehicle driving behaviour only exists when drivers are accustomed to coexisting in an environment of motor traffic density. Also Adams (1995) refers to a reduction in road crashes as a response to increased road perception. And Wilde (1994) postulates, from a homeostatic or self-regulating perspective, that collective risk management mechanisms work as a thermostat, reaching an "optimum" tolerable risk based on the adaptation of driving behaviour: risky driving versus careful driving. After tracing different ethnographic interrelations at black spots on Lisbon's streets and avenues, Moreira (2011) draws attention to the new urban-planning experiences in the Netherlands and Denmark, where an immense uncertainty is being deliberately implemented in places where cars, trucks, cyclists and pedestrians converge, since artificial traffic regulation has been replaced by everyday standards of social interaction. As a result, there has been greater awareness of existing dangers, which has in turn led to fewer serious accidents without affecting the traffic flow (2011: 94).

Returning to the causes of road crashes in Santiago, the sixth and eminently technical reason relates different fields. Since 1967, the hiace vehicle has been designed to take more and more passengers: first 12 , then 15 and finally 18 passengers, in the case of the new models. Personal experience has shown this author more than once that up to 25 or 30 people can be crammed inside, even though some may be children or babies. And often these people will add their own load - as is the case of fishmongers or other types of vendors -, which tends to accumulate in the second and last rows. Such a phenomenal and unquestionably disproportionate load change in a hiace causes a substantial shift in the vehicle's centre of gravity, in stark contrast to the initial determining of a centre of gravity for a much smaller load. Many younger drivers are unaware of this and the results are disastrous: any sudden slamming of the brakes or abrupt change of direction will cause the load being transported to shift and under such circumstances, this very shift can have potentially fatal consequences.

A seventh reason, just as technical and closely related to the previous ones, has to do with the fact that, given the lukewarm police supervision, and precarious presence of traffic lights and manual signalling, the only devices on the roads of Santiago and throughout Cape Verde with the capacity to reduce vehicle speed are speed bumps, which go by the name of quebramolas - literally, "suspension breakers". Made also with cobblestones (unlike some of the speed bumps found in Europe, manufactured with softer materials and 
winding forms, yet not as pronounced), these curved elevations across the road are graphically distinguished from the pavement continuum thanks to bright colours. Despite the fact that drivers usually know where the quebramolas lie in wait, a simple distraction caused by fatigue or speeding, combined with, say, reduced vision at night - due to the non-existence of public lighting at the towns' entrances and exits or at junctions, where the quebramolas are installed are enough to create a context likely to end in an accident. The fact is, many drivers, in an effort to dodge the quebramolas, change the hiace's direction, and attempt to side them diagonally, so that the wheels don't have to pass over the elevation in a pavement that, let's not forget, is made of cobblestones, always on the shoulder of the part of the road where the vehicle is travelling, on the right. In the case of asphalted pavements, speed bumps occupy only one's own lane, so that the driver invades the opposite lane, likewise driving diagonally towards the left so that at least one wheel won't have to withstand the exertion. Breakdowns and damage occur repeatedly in wheels, suspensions and steering, as both drivers and mechanics attest.

As an eighth cause, some even cite the high volume of the music that accompanies the itinerary, since it drowns out any sound signals made by other vehicles and the voices of the passengers announcing their wish to deboard the vehicle at the most unlikely spot. ${ }^{15}$

A ninth and fundamental cause of road crashes lies in the very guidelines of social road conduct prevalent among certain hiace drivers, or what could be called "bad driving" by excellent drivers. Indeed, such drivers stop literally wherever they like, even just beyond an extremely rare traffic sign prohibiting just that: stopping. The widespread disorder results in tie-ups in the midst of a road trip, caused in general by a pedestrian flagging down the vehicle in the hopes of boarding or because a passenger informs the driver, with next to no warning, of the place in which he or she wishes to de-board. I myself have been not only a witness but also an actor in both situations on dozens of occasions. With regard to the prevailing driving styles, it is eye-opening indeed that a driver should choose to stop just after a very tight turn, placing his occupants in harm's way, regardless of his good intentions of picking up a passenger or enabling him to leave the vehicle. In a 1 10-minute trip from Praia to Tarrafal, I witnessed six halts right in the middle of the road, two of which even included considerable backing-up. Another example is the overall refusal to

15 Just as many passengers cannot imagine a trip without music, others find it impossible to rest, think or read with it on. If one asks the driver to turn down the music or simply not to play it, others passengers will protest, which obliges the driver to ask his group of passengers to decide whether or not they want music and, if they want to listen to it, whether they want it at high or low volume. Only once have I witnessed a situation in which the driver substantially lowered the volume of the music at the request of a woman who was breastfeeding her baby, without any objection being raised by the rest of the passengers. 
wear seat belts, even though the driver and first-row passengers are obliged by law to use them.

As the tenth cause, in certain cases this "bad driving" can be attributed to the daily consumption of alcohol by young salaried drivers, something that, like a dog chasing its own tail, brings us back to where we started: the tremendous work pressure that employed drivers have to withstand at times triggers said alcohol consumption, even while on the job, in a process that does not facilitate reasonable hiace driving in the least. This must unquestionably be contextualised within the cultural role of imbibing grogu - the very potent alcoholic beverage of the island, distilled from sugar cane and within reach of humble Cape Verdeans, since beer is out of their price range. It is here that the system of ownership, specifically the one in force for the most part in Praia and Somada, is recognised as a central element for provoking overall high risk situations.

To conclude, yet another reason - the eleventh - is the fact that a considerable number of the vehicles are second-hand, purchased in the Netherlands or the Canary Islands. What's more, the technical maintenance of the vehicle and the official inspections to ensure the obligatory regular checks-ups which hiaces have to pass are lax to say the least.

In view of the prominent role played by hiaces in road crashes, there are a number of concomitant factors depending on different experiences that should be taken into account. To begin with, the drivers' complaints, including those of owner-drivers, go unheeded owing to the indifference of Cape Verde's major labour unions and the absence of a hiace drivers association. Nor is there a hiace passengers association, meaning that at present any type of intervention concerning the organisation of hiace transport depends on the whims of the public administrations. Something as simple as the lack of scheduling leaves the passengers utterly dependent on circumstance, obliged all too often to turn up at the vehicles' departure points well ahead of time, and more so when there is a long distance to be covered, given that it is impossible to accurately predict how long it will take. On occasion, there are interpersonal agreements between passenger and driver that ensure a certain trust that the departure will take place at the appointed time. It should be mentioned that not even the designated pick-up and drop-off points are properly equipped, meaning that passengers must often wait interminably under the blazing central African sun or withstand the desert wind from the continent to the east, without a single shelter or even a bench to sit on. Hence the passengers' own experiences may become paradoxical, since sometimes it is they themselves who urge the driver to go faster. What parameters then are used to measure social risk management?

Yet another element comes to the fore, the importance of which should not be overlooked: it should be stressed that, despite all of the foregoing, 
the working and wage conditions of salaried hiace drivers are an improvement over those of the majority of the working population - converted from escudos into euros, almost $€ 300$ monthly as opposed to under $€ 150$, or even under €100. Historically speaking, working as a hiace driver has become a source of social prestige, since the driver's symbolic status is based on his high social standing - in that many people depend on his work. Regardless of the types of relations that may develop between the driver and female passengers - romantic or sexual, consented or negotiated - the experience of certain young drivers as little road gods ${ }^{16}$ aggravates the likelihood of risk situations. Stronger commitments lead to higher speed or simply degrading service: stopping to drink grogu, or else halting to comply with the requests for a tryst by a girlfriend who lives somewhere along the route (a situation that is perhaps unusual now, but certainly common enough if we look back in time, and which entails a broad spectrum of possibilities in terms of the empirical connotations of the encounter).

At the same time, 2008 proved to be a turning point with respect to the number of passengers. The financial downturn has meant that many people cannot or need not travel, owing to unemployment - as different drivers and residents of different small towns and villages point out -, the consequences of which directly affect the length of working days and the conditions under which the trips are carried out: the drivers are trapped between the need to make the trip cost-effective, which depends on the passengers transported, and the increased amount of time spent recruiting passengers - the waiting time for those already inside the vehicle, which in the case of departure from Praia, at midday or in the afternoon, can be up to two hours, or one hour from Tarrafal to Praia in the morning. This decrease would explain the intensified competition between hiace and taxi drivers in Praia and at its international airport during this period. If one adds the increased number of hiace vehicles in circulation, one begins to grasp the complexity of the situation.

Unquestionably, the political lethargy in the highest decision-making spheres, motivated in theory by the structural lack of material means to get things off the ground, have heretofore frustrated any public regulation of interurban public transport by hiace in all its scope. Though it is impossible to establish with any degree of certainty the different consequences that this would have on the use of space by Cape Verdean pedestrians, one can safely say that in many respects such a regulation would likely be to the further detriment of pedestrians as opposed to motor vehicles. Nonetheless, it would probably also bring about an improvement in both working conditions and in the transport

16 With good reason, Jojada Verrips and Birgit Meyer (2001) show surprise, when studying taxis in Ghana, at the anthropological negligence of the symbolic relevance - power and prestige - of the car and its driver as a basic means of transport in Africa. 
of those concerned, and hence a foreseeable reduction in road crashes in urban and interurban areas. Meetings held with representatives of the Direção-Geral dos Transportes Rodoviários (Directorate-General of Road Transport - DGTR) and, in 2009 and 2010, with Manuel Inocêncio Sousa, Minister of State and Infrastructures, Transport and Telecommunications, have confirmed this.

\section{CONCLUSIONS}

It is hoped that this article, a mere panoramic synthesis of the vast number of processes associated with the uses of space based on the interurban public transport system on the island of Santiago, has provided some insight into the many different social processes, with antagonistic interests on several levels, taking place in this area. This text has sought to relate the analytical perspective and the type of questions and approaches that guide our research into the uses of public space with our specific study objective: the social world of hiaces. After contextualising the social phenomenon of interurban group transport on the island of Santiago, we have analysed, described and discussed 12 possible interrelated causes of road crashes involving hiaces. These causes span a variety of social dimensions that can be synthetically classified into eight main sections: (1) the system of property of hiaces and the labour relations of the salaried drivers and their relationship with speed and driving styles; (2) the technical conditions of pavements and roads, and also the vehicles; (3) the road regulations and the real role played by the traffic police; (4) the antagonistic appropriations of the space by pedestrians and drivers based on different risk perceptions - associated with the hazardous patterns of social and traffic behaviour of many drivers; (5) the conditions in which the hiace journey takes place (with overloading, loud music, consumption of alcohol or other drugs by certain drivers, etc.); (6) the relationship between the driver's symbolic status and the type of behaviour he maintains on the job - greater commitments, higher speed; (7) the tighter competition among drivers to obtain passengers within a growing economic downfall - which delays departure times and prompts higher speed so as not to arrive at the destination too late; and finally (8) the lack of political interest in really getting to the bottom of the consequences of all these questions. Thus, different spheres of Cape Verdean society have been interrelated - economic, legal, political, labour, gender-based, cultural... - which are brought to bear in a particular way in the hiace world.

I must express my gratitude to the people of Cape Verde, to whom this research is dedicated and without whose collaboration and generosity this anthropologist's task would be condemned to the most abject failure. 


\section{REFERENCES}

ADAMS, John, 1995, Risk. London, Routledge.

ALONSO CABRÉ, Marta, and Francesca NUCCI, 2011, "Circulación en la ciudad de Nuakchot: diagnóstico y resolución de accidentes", paper presented at the $12^{\text {th }}$ Meeting of the Spanish Federation of Anthropology Associations of the Spanish State (FAAEE). León, 6-9 September.

AugOYARD, Jean-François, 2010 [1979], Pas à pas. Paris, La Creusée.

BECK, Ulrich, 1992, Risk Society: Towards a New Modernity. London, Sage.

BECK, Ulrich, 1995, Ecological Politics in an Age of Risk. Cambridge, Polity.

BELLABY, Paul, 1990, “To risk or not to risk? Uses and limitations of Mary Douglas on riskacceptability for understanding health and safety at work and road accidents", Sociological Review, 38 (3): 465-483.

BUXÓ, Maria Jesús, 2007, “Antropología aplicada”, in C. Lisón Tolosana (ed.), Introducción a la Antropología Social y Cultural: Teoría, Método y Práctica. Madrid, Akal, 339-355.

BUXÓ, Maria Jesús, and F. TORRIJOS, 1999, Las Culturas del Riesgo y la Seguridad Vial. Barcelona, Fundación Winthertur Publicaciones.

CHOplin, Armelle, 2009, Nouakchott, au carrefour de la Mauritanie et du monde. Paris, Karthala.

DAHOU, Tarik, 2005, "Lespace public face aux apories des études africaines", Cahiers d'Études Africaines, 178: 327-349.

DElgADO, Manuel, 201 1, El Espacio Público como Ideología. Madrid, La Catarata.

DOUGLAS, Mary, 1985, Risk Acceptability According to the Social Sciences. New York, Russell Sage Foundation.

FIORI, Sandra, 2010, "A Malian crossroads as labile mobility place", paper presented at the $7^{\text {th }}$ Iberian Congress on African Studies. Lisbon, 9-1 1 September.

FURTADO, Claudio Alves, 1993, A Transformação das Estruturas Agrárias numa Sociedade em Mudança. Praia, Instituto Caboverdiano do Livro e do Disco.

GEWALD, Jan Bart, Sabine LUNING, and Klaas VAN WALRAVEN (eds.), 2009, The Speed of Change: Motor Vehicles and People in Africa, 1890-2000. Leiden and Boston, Brill.

GOFfMAN, Erving, 1979 [1963], Relaciones en Público: Microestudios del Orden Público. Madrid, Alianza.

HORTA, Gerard, 2004, L'Espai Clos. Fòrum 2004: Notes d'Una Travessia pel No-Res. Barcelona, Edicions de 1984.

HORTA, Gerard, 2010a, Rambla del Raval de Barcelona: De Apropiaciones Viandantes y Procesos Sociales. Barcelona, El Viejo Topo.

HORTA, Gerard, 2010b, "Transporte colectivo en hiace y siniestralidad viaria interurbana en la isla de Santiago (Cabo Verde): primeras notas de campo", paper presented at the $7^{\text {th }}$ Iberian Congress on African Studies. Lisbon, 9-11 September (available at <http://repositorio-iul.iscte.pt/handle/10071/2257?mode=full>).

JACOBS, Jane, 2011 [1961], Muerte y Vida de las Grandes Ciudades. Barcelona, Capitán Swing. JOSEPH, Isaac, 1988 [1984], El Transeúnte y el Espacio Urbano. Barcelona, Gedisa.

LEDRUT, Raymond, 1973, Les images de la ville. Paris, Anthropos.

Lefebvre, Henri, 1976, Espacio y Política: El Derecho a la Ciudad. Barcelona, Península.

LEFEBVRE, Henri, 1991, The Production of Space. Malden, MA, and London, Blackwell Publishers. 
LÉVI-STRAUSS, Claude, 1991 [1950], "Introducción a la obra de Marcel Mauss", in Marcel Mauss, Sociología y Antropología. Madrid, Tecnos, 13-42.

LOFLAND, Lyn H., 1985 [1973], A World of Strangers: Order and Action in Urban Public Space. Prospect Heights, IL, Waveland Press.

LOFLAND, John, and Lyn H. LOFLAND, 1984, Analyzing Social Settings: A Guide to Qualitative Observation and Analysis. Belmont, CA, Wadsworth Publishing Company ( $2^{\text {nd }}$ edition).

LOPES, Carlos, 2009, "Hug me, hold me tight! The evolution of passenger transport in Luanda and Huambo (Angola), 1975-2000”, in J. B. Gewald, S. Luning, and K. Walraven (eds.), The Speed of Change: Motor Vehicles and People in Africa, 1890-2000. Boston, Brill, 105-126.

LOPES, Carlos, 2010, "Dinâmicas do associativismo na economia informal: os transportes de passageiros em Angola”, Análise Social, XLV (195): 367-391.

LOPES, Carlos, 2011 , Candongueiros \& Kupatatas: Acumulação, Risco e Sobrevivência na Economia Informal em Angola, Luanda. Cascais, Principia.

LOPES FILHO, João, 2006, Cabo Verde. Abolição da Escravatura: Subsídios para o Estudo. Praia, Spleen.

LYNCH, Kevin, 1985, La Buena Forma de la Ciudad. Barcelona, Gustavo Gili.

MALET, Daniel, 201 1, "Las apropiaciones socioespaciales del sistema hiace en el mercado de Sucupira de Praia (isla de Santiago, Cabo Verde)", paper presented at the $12^{\text {th }}$ Meeting of the Spanish Federation of Anthropology Associations of the Spanish State (FAAEE). León, 6-9 September.

MAUSS, Marcel, 1991 [1923-1924], "Ensayo sobre los dones: Razón y forma del cambio en sociedades primitivas", in Marcel Mauss, Sociología y Antropología. Madrid, Tecnos, 155-263.

MONTORO, Luis, 2005, "La percepción de la seguridad y del riesgo en el tráfico: los modelos cognitivos motivadores", paper presented at the V Symposium on Road Anthropology. Barcelona, Fundación Abertis, 28 October.

MOREIRA, Ana Rita, 2011 , "A percepção do risco e as ZAA", in M. J. Ramos (ed.), Risco e Trauma Rodoviários em Portugal. Lisbon, Associação de Cidadãos Auto-Mobilizados, 87-97.

RAMOS, Manuel João, 2011 , "Prefácio", in M.J. Ramos (ed.), Risco e Trauma Rodoviários em Portugal. Lisbon, Associação de Cidadãos Auto-Mobilizados, 9-13.

RAPOPORT, Amos, 1978, Aspectos Humanos de la Forma Urbana. Barcelona, Gustavo Gili. RIBAS, Clara, 2010, "Barcelona participa en la remodelació d'una rambla de Maputo, a Moçambic”, El Punt, Barcelona, 4 March 2010: 8.

SMEED, Ruben Jacob, 1974, "The frequency of road accidents", Zeitschrift für Verkehrssicherheit, 20 (23): 51-59 and 95-107.

VERRIPS, Jojada, and Birgit MEYER, 2001, "Kwaku's car: the struggles and stories of a Ghanaian long-distance taxi driver”, in Daniel Miller (ed.), Car Cultures. Oxford, Berg, 153-184.

WHYTE, William H., 1988, City: Rediscovering the Center. New York, Doubleday.

WILDE, Gerald, 1994, Target Risk. Toronto, PDE Publications. 